\title{
Clinical associations of IgG antibodies to the ribonucleoprotein p67 polypeptide in patients with systemic lupus erythematosus
}

\author{
J Vencovsky, D G Williams, M Field, R N Maini
}

\begin{abstract}
The ribonucleoprotein (RNP) p67 antigen was purified from rabbit thymus and used in an enzyme linked immunosorbent assay (ELISA) with low interassay variability to detect IgG antibodies to $\mathrm{p} 67$ in patients with autoimmune connective tissue diseases. These antibodies were found in eight $(80 \%)$ patients with a clinical diagnosis of mixed connective tissue disease (MCTD) but also in 27 (40\%) patients with systemic lupus erythematosus (SLE). Sixty six per cent of the 12 patients with SLE with high levels of antibodies to p67 (>50 U) had three or more features of MCTD, including myositis, fibrosing alveolitis, Raynaud's phenomenon, and sclerodactyly. Antibodies to the p67 RNP were not associated with the presence or absence of renal disease in the patients with SLE. This study suggests that antibodies against the p67 RNP are markers for clinical features of MCTD even in the context of SLE.
\end{abstract}

(Ann Rheum Dis 1992; 51: 1313-1317)

High titres of antibodies to nuclear ribonucleoprotein (nRNP) in the absence of antibodies to Sm are reported to occur in $95-100 \%$ of patients with mixed connective tissue disease (MCTD) but rarely in patients with systemic lupus erythematosus (SLE) and progressive systemic sclerosis. ${ }^{1}$ Serum samples that have antibodies to the RNP antigen immunoprecipitate Ul snRNA-protein complexes, which contain a set of at least nine proteins denoted p67 and A-G. ${ }^{2}{ }^{3}$ Antibodies to nRNP bind to three polypeptides in this complex: p67, $\mathrm{A}$, and $\mathrm{C}$ (molecular weight 67, 33, and 20 kilodaltons respectively). ${ }^{45}$ Antibodies against the $\mathrm{A}$ and $\mathrm{C}$ polypeptides are found in patients with MCTD and SLE, but it has been suggested that antibodies to p67 are restricted to patients with MCTD. 356

Current techniques of autoantibody detection such as immunodiffusion, passive haemagglutination, ${ }^{7}$ or counterimmunoelectrophoresis ${ }^{8}$ measure the total amount of antibodies to RNP against all three peptides p67, A, and C. Direct detection of antibodies to individual specific RNP polypeptides has been achieved by immunoblotting ${ }^{49} 10$ and enzyme linked immunosorbent assay (ELISA) using natural antigen ${ }^{11}$ or recombinant antigen. ${ }^{12}{ }^{13}$ The aim of this study was to examine the possibility of using naturally occurring RNP p67 antigenic polypeptide in an ELISA for the routine detection and measurement of antibodies to p67, and to investigate the clinical correlations of this antibody in patients with SLE.
Patients and methods

PATIENTS, SERUM SAMPLES, AND ANTIBODIES

We used serum samples from five disease groups. (a) Twenty patients with dermatomyositis/polymyositis complex diagnosed according to the criteria of Bohan and Peter. ${ }^{14}(b)$ Ten patients with at least three of the following features of MCTD: Raynaud's phenomenon, fibrosing alveolitis, sausage shaped fingers and toes, sclerodactyly, arthritis, or myositis. They were diagnosed without reference to the presence of the antibody to RNP and none of them fulfilled four or more American Rheumatism Association (ARA) criteria for SLE or had antibodies to Jo-l present in their serum samples. (c) Sixty seven patients with SLE diagnosed using the ARA criteria. ${ }^{15}$ (d) Forty eight patients with Raynaud's phenomenon. $(e)$ Thirteen patients with progressive systemic sclerosis. ${ }^{16}$

Forty six normal serum samples were obtained from volunteer office staff (British Oxygen Company Ltd). The serum samples were used at a dilution of $1 / 100$.

The murine monoclonal antibodies used were derived from fusions of MRL/lpr spleen cells. The $\mathrm{Sm}$ antibodies $\mathrm{KSm} 2$ (anti-D) and $\mathrm{KSm} 5$ (anti-B, $B^{\prime}$ ) were used as ascitic fluid, ${ }^{6}$ and were used at a dilution that produces an absorbance greater than $2 \cdot 0$ in assays using the $\mathbf{B B}^{\prime}$ and $\mathrm{D}$ antigens respectively. The RNP antibody $\mathrm{K} 8-43$, directed against p67, was used at a dilution of $1 / 10$ of the cell culture supernatant.

\section{ANTIGEN ISOLATION}

Rabbit nRNP/Sm polypeptides were isolated from thymus acetone powder (PelFreeze Biological, Rogers, AR, USA) as described previously. ${ }^{11}$ Five batches of p67 antigen were prepared and stored in glass tubes for one to seven weeks at $4^{\circ} \mathrm{C}$. The protein content of the fractions was estimated with the BCA protein assay reagent (Pierce, Rockford, IL, USA) using an albumin calibration graph. The eluate was assessed by gel electrophoresis and immunoblotting. ${ }^{9}$

\section{PURITY OF p67 ANTIGENS}

Antigenic purity was checked by immunoblotting and ELISA. The proteins from each of the batches were separated by sodium dodecylsulphate polyacrylamide gel electrophoresis, transferred to nitrocellulose paper, ${ }^{9}$ and probed with either human serum containing antibody to RNP or monoclonal antibody K8-43. To confirm that the antigen preparation did not 
contain any contaminating Sm polypeptides the separated antigen preparation was probed with the $\mathrm{KSm} 2$ and $\mathrm{KSm} 5$ monoclonal antibodies against the $\mathrm{D}$ and $\mathrm{B}, \mathrm{B}^{\prime} \mathrm{Sm}$ antigens respectively. ${ }^{11}$

The p67 polypeptides from individual batches were coated onto microtitre plates for an ELISA. ${ }^{11}$ The antigens were assessed with reference human serum containing antibodies to $\mathrm{RNP} / \mathrm{Sm}$ and with normal human serum, or the monoclonal antibodies K8-43 (antibody to p67), KSm2 (antibody to D), and KSm5 (antibody to $\mathrm{BB}^{\prime}$ ), detected with an antihuman or antimouse IgG antibody linked to alkaline phosphatase (Sigma) followed by Sigma 104 substrate.

ENZYME LINKED IMMUNOSORBENT ASSAY

To establish the optimum concentration of antigen for coating the ELISA plates for use in the assay of patients' serum samples an initial 'chequerboard titration' of the p67 antigen was carried out. Antigen was coated onto ELISA plates at $5 \cdot 0,2 \cdot 5,1 \cdot 2,0 \cdot 6,0 \cdot 3$, and $0 \cdot 15 \mu \mathrm{g} / \mathrm{ml}$

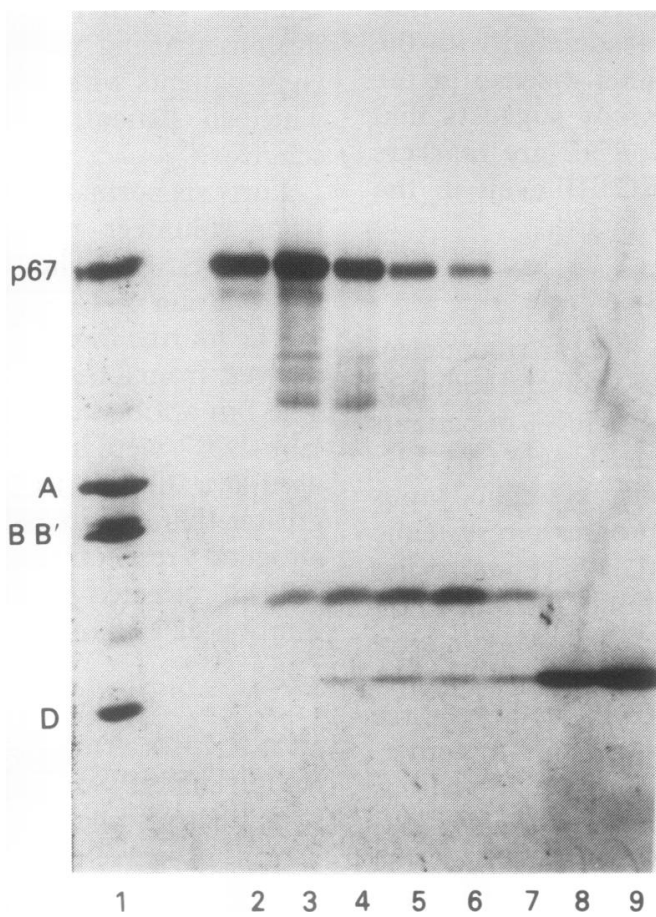

Figure 1 Immunoblotting analysis of consecutive fractions from reversed phase column chromatography of rabbit $R N P / S m$ (tracks 2-9). Track 1 is a whole RNP/Sm antigen with $p 67$ (67 kilodaltons), $A$ (33 kilodaltons), $B, B^{\prime}(29,28$ kilodaltons), and $D$ (16 kilodaltons) peptides. The fraction shown in track 2 is uncontaminated p67 which was used for the immunoassay.

Table 1 Reproducible antibody specificity of 067 antigen. Values are duplicate results obtained in the enzyme linked immunosorbent assay (ELISA) using the human antibody obtained in the enzyme linked immunosorbent assay (ELISA) using the human antibody
against $p 67(R N P s)$, normal human serum (NHS), and the three monoclonal antibodies against $B, B^{\prime}(K S m 5), D(K S m 2)$, and $p 67(K 8-43)$ on the purified $p 67$ antigen

\begin{tabular}{|c|c|c|c|c|c|}
\hline \multirow{2}{*}{$\begin{array}{l}\text { Batch } \\
\text { of p67 }\end{array}$} & \multicolumn{5}{|c|}{ Absorbance at $405 \mathrm{~nm}$ of ELISA well incubated with } \\
\hline & $K S m 2$ & $K S m 5$ & $K 8-43$ & RNPs & NHS \\
\hline $\begin{array}{l}1 \\
2 \\
3 \\
4 \\
5\end{array}$ & $\begin{array}{l}0.025 \\
0.028 \\
0.032 \\
0.033 \\
0.034\end{array}$ & $\begin{array}{l}0.022 \\
0.039 \\
0.019 \\
0.040 \\
0.055\end{array}$ & $\begin{array}{l}1 \cdot 53 \\
2 \cdot 47 \\
2 \cdot 58 \\
2 \cdot 70 \\
2 \cdot 76\end{array}$ & $\begin{array}{l}1.85 \\
1.86 \\
1.90 \\
1.92 \\
1.85\end{array}$ & $\begin{array}{l}0 \cdot 097 \\
0 \cdot 097 \\
0 \cdot 120 \\
0 \cdot 093 \\
0 \cdot 116\end{array}$ \\
\hline
\end{tabular}

and probed with reference serum samples containing antibodies to p67 and normal serum samples at dilutions of $1 / 50,1 / 100$, and $1 / 200$. For a working antigen dilution we used the concentrations which gave an absorbance (405 $\mathrm{nm})$ of 1.5 with the reference serum after one hour's incubation with the ELISA substrate: $2 \cdot 5 \mu \mathrm{g} / \mathrm{ml}$ (preparation 1 ) and $1 \cdot 2 \mu \mathrm{g} / \mathrm{ml}$ (preparations 2-5).

Plates were stored sealed at $4^{\circ} \mathrm{C}$. The ELISA on the serum samples was performed using a method modified from that of Williams et al ${ }^{11}$ using a standard graph constructed by serial dilution of a human reference serum sample in duplicate.

\section{STATISTICAL METHODS}

Data were analysed using the $\chi^{2}$ test. The analysis of variance ( $F$ test) was used for comparison of means.

\section{Results}

PROTEIN PURITY OF $\mathrm{p} 67$

Fractions of reversed phase column eluate were electrophoresed, blotted, and probed with a mixture of antibodies to nRNP and Sm. Densitometry of stained gel electrophoretograms showed the protein purity of isolated p67 antigens to be $75,82,84$, and $87 \%$. Immunoblotting showed that the column fractions indicated the presence of p67 antigen in early eluting fractions from the reversed phase column (tracks 2-6; fig 1). Some fractions were contaminated with several weak immunoreactive bands with molecular weights of $64,54,45$, and 21 kilodaltons (tracks 3 and 4), which may be degradation products of p67. Later fractions (tracks 5 and 6) containing p67 were also contaminated with $\mathrm{D}$ peptide and were discarded. The protein content of the fractions from five different preparations ranged from 25 to $41 \mu \mathrm{g} / \mathrm{ml}$, giving a yield of pure peptides of between 100 and $164 \mu \mathrm{g}$ from $5 \mathrm{~g}$ of rabbit thymus powder.

ANTIGENIC PURITY OF p67 ANTIGEN

Although the monoclonal antibody to p67 (K8-43) and a human serum sample containing antibodies to RNP bound in the ELISA to the purified p67 antigen from each preparation, the monoclonal antibodies $\mathrm{KSm} 5$ and $\mathrm{KSm} 2$ did

Table 2 Interbatch variation of p67 antigen in six human serum samples containing antibodies to ribonucleoprotein determined by enzyme linked immunosorbent assay. Values are levels of antibody to p67 (U)

\begin{tabular}{lcccccr}
\hline $\begin{array}{l}\text { Batch } \\
\text { of } p 67\end{array}$ & \multicolumn{6}{l}{ Serum sample No } \\
\cline { 2 - 7 } & $I$ & $I I$ & $I I I$ & $I V$ & $V$ & $V I$ \\
\hline 1 & $8 \cdot 1$ & 14 & 16 & 26 & 58 & 79 \\
2 & $7 \cdot 0$ & 14 & 20 & 28 & 65 & 101 \\
3 & $7 \cdot 3$ & 17 & 21 & 27 & 58 & 110 \\
4 & $7 \cdot 7$ & 20 & 22 & 29 & 60 & 99 \\
5 & $9 \cdot 6$ & 12 & 16 & 27 & 45 & 112 \\
$\begin{array}{l}\text { Mean } \\
\text { Standard } \\
\text { deviation }\end{array}$ & $7 \cdot 9$ & 15 & 19 & 27 & 57 & 100 \\
$\begin{array}{c}\text { Coefficient of } \\
\text { variation (\%) }\end{array}$ & 13 & $3 \cdot 3$ & $2 \cdot 7$ & $1 \cdot 7$ & $7 \cdot 4$ & 13 \\
\hline
\end{tabular}


not (table 1), confirming that this technique of immunoaffinity chromatography and high performance liquid chromatography can produce pure p67 antigen in a reproducible manner without contamination with the $B, B^{\prime}$, and $D$ polypeptides from the Sm antigen.

\section{COMPARISON OF INDIVIDUAL PREPARATIONS}

OF $\mathrm{p} 67$

The p67 antigens were diluted with phosphate

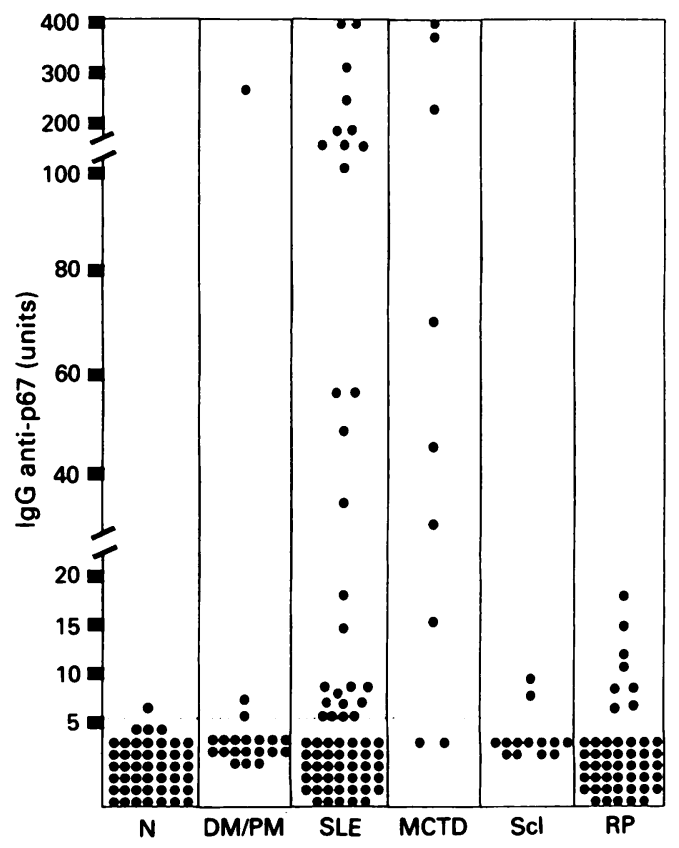

Figure 2 Distribution of $\operatorname{Ig} G$ antibodies to $p 67$ in the disease groups studied. $N=$ normal controls $(n=46)$; $D M / P M=$ dermatomyositis/polymyositis $(n=20)$;

$S L E=$ systemic lupus erythematosus $(n=67)$;

$M C T D=$ mixed connective tissue disease $(n=10)$.

$S c l=$ scleroderma $(n=13) ; R P=$ Raynaud's phenomenon $(n=48)$.

Table 3 Associations of increased antibodies to p67 with some clinical features of mixed connective tissue disease in patients with systemic lupus erythematosus

\begin{tabular}{llll}
\hline Clinical feature & $\begin{array}{l}\text { Positive for } \\
\text { antibodies to } p 67 \\
(n=27)\end{array}$ & $\begin{array}{l}\text { Negative for } \\
\text { antibodies to } 067 \\
(n=40)\end{array}$ & $p$ Value \\
\hline Renal disease $(n=38)$ & 18 & 20 & NS \\
Alveolitis $(n=15)$ & 8 & 7 & NS \\
Raynaud's phenomenon $(n=39)$ & 17 & 22 & $0 \cdot 019$ \\
Myositis $(n=10)$ & 8 & 2 & NS \\
Arthritis $(n=57)$ & 23 & 34 & \\
\hline
\end{tabular}

buffered saline and coated onto ELISA plates as described. To confirm the reproducibility of the assay the binding of six reference serum samples with low to high binding activity to RNP was measured on each preparation (table 2). The coefficients of variation for individual serum samples were $13,22,14,6,13$, and $13 \%$.

ANTIBODIES TO p67 IN AUTOIMMUNE CONNECTIVE TISSUE DISEASES

The upper limit of the normal range of antibodies to $\mathrm{p} 67$ (mean + three standard deviations) was $5 \cdot 1$ units, determined using serum samples from 46 healthy subjects (fig 2). Using this limit one normal subject had increased levels of antibodies against p67 (6 U). Increased levels of these antibodies were also seen in $3 / 20(15 \%)$ patients with myositis, $8 / 10(80 \%)$ with MCTD, $27 / 67(40 \%)$ patients with SLE, $2 / 13$ (15\%) with progressive systemic sclerosis, and $8 / 48(17 \%)$ with Raynaud's phenomenon. Our previous studies have suggested that levels of antibody to p67 greater than $50 \mathrm{U}$ may be restricted to patients with MCTD. ${ }^{11}$ High titres (>50 U) were found in $5 / 10(50 \%)$ of the patients with MCTD, 12/67 (18\%) of those with SLE, and $1 / 20$ (5\%) patients with dermatomyositis/ polymyositis complex (fig 2 ).

\section{CLINICAL FEATURES OF PATIENTS WITH}

SLE WITH ANTIBODIES TO $p 67$

Patients with SLE were assessed for the presence of renal disease and the major clinical features of MCTD, ${ }^{7}$ and then separated according to the presence or absence of antibodies against the p67 antigen (table 3). This showed that the incidence of renal disease, lung fibrosis, arthritis, and Raynaud's phenomenon was similar in the two groups, but that the antibodies to p67 were detected more often when myositis was a feature of the SLE $(p=0.019)$. The mean antibody titre to $p 67$ was also significantly higher in patients with myositis (122 U) than those without (31 U) ( $\mathrm{p}=0.003$ using the $F$ test). In addition, in the patients with SLE with features of MCTD (alveolitis, Raynaud's phenomenon, myositis, and arthritis) the mean antibody titre to p67 was higher (167 U) than in those without these clinical features $(33 \mathrm{U})(\mathrm{p}<0.001)$.

Table 4 Association of high levels (>50 U) of antibodies to p67 with patients with systemic lupus erythematosus (SLE) and features of mixed connective tissue disease

\begin{tabular}{|c|c|c|c|c|c|c|c|c|c|}
\hline $\begin{array}{l}\text { Patient } \\
\text { No }\end{array}$ & $\begin{array}{l}\text { No of SLE } \\
\text { criteria }\end{array}$ & $\begin{array}{l}p 67 \text { titre } \\
(U)\end{array}$ & Synovitis & $\begin{array}{l}\text { Raynaud's } \\
\text { phenomenon }\end{array}$ & Sclerodactyly & Myositis" & $\begin{array}{l}\text { Lung } \\
\text { diseaset }\end{array}$ & $\begin{array}{l}\text { Oesophageal } \\
\text { disease } \neq\end{array}$ & $\begin{array}{l}\text { Renal } \\
\text { disease }\end{array}$ \\
\hline 1 & 8 & 145 & + & - & + & + & + & - & - \\
\hline 2 & 9 & 400 & + & + & + & + & + & NR & + \\
\hline 3 & 4 & 232 & + & + & + & - & + & + & - \\
\hline 4 & 7 & 90 & + & + & + & + & + & NR & - \\
\hline 5 & 9 & 55 & + & + & + & + & + & + & - \\
\hline 6 & 9 & 55 & + & + & + & + & + & + & - \\
\hline 7 & 9 & 130 & + & + & - & + & - & + & + \\
\hline 8 & 10 & 160 & + & + & $+\mathbb{I}$ & + & + & + & + \\
\hline 9 & 11 & 160 & + & - & NR & - & + & + & + \\
\hline 10 & 7 & 409 & + & + & + & - & + & NR & + \\
\hline 11 & 10 & 300 & + & +5 & + & + & + & - & + \\
\hline 12 & 7 & 129 & + & + & - & - & + & - & + \\
\hline
\end{tabular}

Abbreviations: (+) Present; (-) not present; (NR) no record.

*Two or more criteria as defined by Bohan and Peter. ${ }^{1}$

†Either low $K_{(\infty)}$ or crepitations.

$\ddagger$ Detected either clinically or radiographically.

§Developed during illness.

ๆTemporary. 
In the group of 12 patients with SLE with more than $50 \mathrm{U}$ of antibody to p67 (table 4) there was a high incidence of synovitis $(100 \%)$, Raynaud's phenomenon (85\%), sclerodactyly (75\%), and myositis (75\%), and $75 \%$ had decreased lung function. Five of 12 patients (42\%) had four features of MCTD, three of 12 $(25 \%)$ had three features, and four of $12(33 \%)$ had two features of MCTD. Antibodies against p67 were present in seven of $12(58 \%)$ patients with renal disease and five of $12(42 \%)$ without (table 4), implying that these antibodies neither protect nor predispose patients with SLE to develop renal changes.

Thus $66 \%(8 / 12)$ of this subset of patients with SLE fulfilled three or more clinical criteria for MCTD, suggesting that high levels of antibodies to p67 delineate a group of patients with SLE who also have criteria for MCTD and thus may represent an overlap group between these two diseases.

\section{Discussion}

These results confirm that it is possible to prepare reproducibly pure p67 RNP antigen from rabbit thymus extract by a process of immunoaffinity and high performance liquid chromatography. ${ }^{11}$ This technique produces antigen free from contamination with Sm polypeptides or other proteins as detected by immunoblotting and ELISA. The resultant antigen preparations can thus be used in a standard immunoassay provided each preparation is standardised using a chequerboard titration. Furthermore it is possible to use such low concentrations of antigen $(1 \cdot 2-2.5 \mu \mathrm{g} / \mathrm{ml})$ that large numbers of microtitre plates can be prepared from one antigen purification, thus the assay can readily be used in routine laboratory experiments.

In the initial description of MCTD it was thought that the presence of high titres of antibodies to the nRNP antigen could be used as a serological marker for this distinct connective tissue disease. ${ }^{7}$ Low levels of antibodies to RNP can be detected in many patients with other connective tissue diseases, however, as well as in a small percentage of normal subjects. ${ }^{14}$ Early studies using immunoblotting suggested that the antibodies against the p67 antigen were found only in patients with MCTD and not in patients with SLE. ${ }^{356}$ Our study aimed to investigate the occurrence of antibodies against the p67 antigen in patients with connective tissue diseases using the ELISA technique.

We have shown that antibodies to p67 above $5 \mathrm{U}$ (mean + three SD of 46 normal subjects) were found in $8 / 10(80 \%)$ patients with a clinical diagnosis of MCTD (based on only the clinical criteria of Sharp $\left.e t \mathrm{al}^{7}\right)$. We also found increased levels in 27/67 $(40 \%)$ patients with SLE, however, as well as $15 \%$ of patients with polymyositis/dermatomyositis, $8 / 48 \quad(17 \%)$ with Raynaud's phenomenon and 1/46 (2\%) healthy subjects. This confirms that antibodies against the p67 antigen are found in low titres in a wide spectrum of patients. ${ }^{17}$

High levels of antibodies to p67 (defined as $>50 \mathrm{U} / \mathrm{ml}$ ) were found only in the patients with connective tissue diseases (5/10 (50\%) patients with MCTD, 12/67 (18\%) patients with SLE, and 1/20 (5\%) patients with dermatomyositis/polymyositis). During the course of the latter patient's disease systemic features developed, including Raynaud's phenomenon, decreased pulmonary diffusion capacity, dysphagia, oesophageal abnormalities on contrast radiographs, and finally digital vasculitis. Thus according to proposed clinical criteria, ${ }^{7}$ she can now be considered as having MCTD. Hence high titres of antibodies to p67 occur only in patients with MCTD and SLE. This is in agreement with other studies that have shown the presence of antibodies to p67 in patients with SLE by ELISA using a recombinant p70 antigen ${ }^{12}$ and using immunoblotting. 9 10

To investigate whether antibodies to p67 were associated with features of MCTD we selected 67 patients fulfilling four or more ARA criteria for SLE and examined them for features of MCTD and the presence of antibodies to p67. Our findings did not confirm the protective influence of antibodies to p67 against renal changes in the SLE group. ${ }^{78}$ Not only was the number of patients with SLE and renal disease almost identical to that in the group without renal disease, but also the mean values of antibodies to p67 in the group with and without renal disease were not statistically different.

The patients with SLE with antibodies to p67 at any titre often have clinical features of MCTD, however, particularly myositis (80\%). This implies that antibodies to p67 are not restricted to MCTD but are particularly associated with myositis, which may be found in patients with MCTD and SLE. This confirms a previous study which often found the presence of MCTD features in patients with SLE, ${ }^{19}$ and suggests that these antibodies may be a useful marker for these features in either group.

This is further corroborated by analysis of those patients with high titres of antibodies to p67 (table 4), as in this group of 12 patients with SLE $75 \%$ had myositis. The occurrence of other features of MCTD including sclerodactyly and reduced lung function was $75 \%$, and all these patients had synovitis. In addition, the incidence of renal disease in these patients was similar in those with and without antibodies to RNP, which is in agreement with the data for the SLE group as a whole.

These results show that high levels of antibodies to p67 determined by ELISA are common in patients with MCTD but are also present in some patients with SLE. In this group of patients with SLE clinical features of MCTD are also seen, suggesting that the patients with SLE with antibodies to p67 form a subgroup of SLE/MCTD.

We thank the Wellcome Trust and the Arthritis and Rheumatism Council for financial support.

1 Sharp G C, Alspaugh M A. Autoantibodies to nonhistone nuclear antigens. Their immunobiology and clinical nuclear antigens. Their immunobiology and clinical relevance. In: Gupta S, Talal N, eds. Immunobiologv of rheumatic diseases. New York and London: Plenum, 1985:

2 Lerner M R, Steitz J A. Antibodies to small nuclear RNAs 
complexed with proteins are produced by patients with systemic lupus erythematosus. Proc Natl Acad Sci USA 1979; 76: 5495-9.

3 Pettersson I, Wang G, Smith E I, et al. The use of immunoblotting and immunoprecipitation of (U) small nuclear ribonucleoproteins in the analysis of sera of patients with mixed connective tissue disease and systemic lupus with mixed connective tissue disease and systemic
erythematosus. Arthritis Rheum 1986; 29: 986-96.

4 Pettersson I, Hinterberger M, Mimori T, Gottlieb E, Steitz $\mathrm{J} A$. The structure of mammalian small nuclear ribonucleoproteins. F Biol Chem 1984; 259: 5907-14.

5 Habets W J, deRooij D J, Hoet $M$ H, van de Putte $L$ B, van Venrooij W J. Quantitation of anti-RNP and anti-Sm antibodies in MCTD and SLE patients by immunoblotting. Clin Exp Immunol 1985; 59: 457-66. 6 van Venrooij W J. Autoantibodies against small nuclear (suppl 13): 78-82.

7 Sharp G C, Irvin W S, Tan E M, Gould G R, Holman H R. Mixed connective tissue disease-an apparently distinct rheumatic disease syndrome associated with a specific rheumatic disease syndrome associated with a specific antibody to an extractable

8 Kurata N, Tan E M. Identification of antibodies to nuclear acidic antigens by counterimmunoelectrophoresis. Arthritis Rheum 1976; 19: 574-80.

9 Williams D G, Stocks M R, Charles P J, Maini R N. Antibodies to $\mathrm{La}, \mathrm{Jo}-1, \mathrm{nRNP}$ and $\mathrm{Sm}$ detected by multitrack immunoblotting using a novel filter holder: a comparative study with counterimmunoelectrophoresis and immunodiffusion using sera from patients with systemic lupus erythematosus and Sjögren's syndrome. $f$ Immunol Methods 1986; 91: 65-73.

10 Combe B, Rucheton M, Graafland H, Lussiez V, Brunel C,
Sany J. Clinical significance of anti-RNP and anti-Sm autoantibodies as determined by immunoblotting and immunoprecipitation in sera from patients with connective immunoprecipitation in sera from patients with connective
tissue diseases. Clin Exp Immunol 1989; 75: 18-24.

11 tissue diseases. Clin Exp Immunol 1989; 75: 18-24. of p67, A, B, B' and D from nRNP/Sm and Sm antigens by reverse-phase chromatography: use in polypeptide-specific ELISA for independent quantitation of anti-RNP and antiSm antibodies. F Immunol Methods 1988; 113: 25-35.

12 Netter H J, Guldner H H, Szostecki C, Lakomek H J, Will $H$. A recombinant autoantigen derived from the human (U1) small nuclear RNP-specific $68-\mathrm{kD}$ protein. Arthritis Rheum 1988; 31: 616-22.

13 Habets W J A, Hoet M H, Sillekens P T G, de Rooij D J R A M, van de Putte L B A, van Venrooij W J. Detection of autoantibodies in a quantitative immunoassay using recombinant ribonucleoprotein antigens. Clin Exp Immunol 1989; 76: 172-7.

14 Bohan A, Peter J B. Polymyositis and dermatomyositis. N Engl Y Med 1975; 292: 344-7.

15 Tan E M, Cohen A S, Fries J F, et al. The 1982 revised criteria for the classification of systemic lupus erythematosus. Arthritis Rheum 1988; 25: 1271-7.

16 Masi A T, Rodnan G P, Medsger T A. Preliminary criteria for the classification of systemic sclerosis (scleroderma). Bull Rheum Dis 1981; 31: 1-6.

17 Notman D D, Kurata N, Tan E M. Profiles of antinuclear antibodies in systemic rheumatic diseases. Ann Intern Med 1975; 83: 464-9.

18 Sharp G C. Subsets of SLE and mixed connective tissue disease. Am f Kidney Dis 1982; 11: 201-5.

19 Alarcon-Segovia D, Cardiel M H. Comparison between 3 diagnostic criteria for mixed connective tissue disease. Study of 593 patients. F R heumatol 1989; 16: 328-34. 